\title{
BACTEROIDES CORRODENS AND EIKENELLA CORRODENS
}

\author{
Dr. S. P. LAPAGE, M.B., B.S., F.R.C.Path., L.M.S.S.A., Dip.Bact. \\ Mr. J. J. S. SNELL, M.Phil. \\ National Collection of Type Cultures \\ Central Public Health Laboratory, Colindale
}

\section{Foreword}

A Non-commissioned officer, aged 30 years, was admitted to a military hospital suffering from a chronic suppurative otitis media condition, which necessitated suction clearance.

On examination by the E.N.T. Surgeon he was found to have mucopus in the external auditory meatus, the whole tympanic membrane was boggy and oedematous; the site of perforation was not definable.

From the pus swab an organism was isolated with unusual features such that the species identification could not be accomplished at the military hospital pathology department, nor at the department of pathology (Microbiology) of the Royal Army Medical College. It was therefore forwarded to the Curator of the National Collection of Type Cultures, Colindale, London, who very kindly identified the Gram-negative organism as Eikenella corrodens; as far as we know this is the first time that this organism has been reported from any military hospital and it is certainly the first time that it has been reported in the pages of this Journal.

Editor

\section{Introduction}

Small Gram-negative nonsaccharolytic bacteria that pit the surface of agar media and grow best under reduced oxygen tension have been classified as Bacteroides corrodens. Jackson et al (1971) made a distinction between the strict anaerobes (Bacteroides corrodens) and strains growing in air or air $+\mathrm{CO}_{2}$ (Eikenella corrodens).

\section{Eikenella corrodens}

These strains are frequently isolated from clinical material. The natural habitat appears to be the upper respiratory tract of man. Sites of isolation of strains sent to the National Collection of Type Cultures include a variety of abscesses (brain, liver, perinephric, finger, subphrenic, cervical, clitoral, lung, neck, jaw, appendix and submandibular) and other sites including sputum, pleural fluid and colostomy wound: Reports from the literature cite isolation from respiratory tract abscess, and blood cultures following dental extraction.

The phenotypic characterization of $E$. corrodens has been discussed by Hill, Snell and Lapage (1970). Although the strains may prefer anaerobic conditions plus $\mathrm{CO}_{\mathbf{2}}$ or air plus $\mathrm{CO}_{2}$ on first isolation, after subculture they grow well under aerobic conditions. The characteristic 'pitting' or corrosion of the agar surface is not an invariant character as several non-pitting strains have been examined. The characteristics of these bacteria are: Gram-negative rods, nonmotile, non-saccharolytic, urease, caseinase, gelatinase, and catalase negative. The oxidase test is positive, nitrates are reduced and ornithine and lysine decarboxylases are produced. The Deoxyribonucleic acid (DNA) 
base composition is in the range 56.2- $-58.2 \%$ Guanine + cystosine (GC) The combination of results: oxidase positive, catalase negative, nitrates reduced and ornithine and lysine decarboxylated is unique to $E$. corrodens and provides a ready means of identification.

\section{Bacteroides corrodens}

This species appears to be less frequently isolated than E.corrodens, the natural habitat is not known with certainty. The National Collection of Type Cultures has received strains for identification and combined with the strains of Jackson et al (1971), the organism has been isolated from sputum, lung biopsy, vagina, amniotic fluid, face lesions and an infected heel. Jackson et al (1971) found a similar pattern of test results to E.corrodens but B.corrodens differed in failing to grow aerobically, in producing urease, gelatinase and caseinase and giving negative results for lysine decarboxylase. The range of DNA base composition $(28-29.7 \% \mathrm{GC})$ was significantly lower than that of Eikenella strains and the two groups appeared serologically unrelated.

\section{REFERENCES}

HILl, L. R., SNeLl, J. J. S. and LAPAGE, S. P. (1970). Identification and characterisation of Bacteroides corrodens. J. med. Microbiol. 3, 483.

Jackson, F. L., Goodman, Y. F., BeL, F. R., Wong, P. C. and Whitehouse, R. L. S. (1971). Taxonomic status of facultative and strictly" anaerobic "Corroding Bacilli" that have been classified as Bacteroides corrodens. J. med. Mierobiol. 4, 171.

\section{ACADEMIC ACHIEVEMENTS}

F.R.C.P.(Ed.) ～LIfUTENANT-Colonel T. C. Hindson, M.A., M.B., B.chir., M.R.C.P.(Lond.), M.R.C.P. (Ed.), D.T.M.\&H., R.A.M.C.

F.R.C.S.

M.R.C.G.P.

MAJOR P. F. T. SEWell, M.B., B.chir., R.A.M.C.

LIEUTENANT-COLONEL H. A. WILliAMS, M.B., B.S., L.M.S.S.A., D.T.M.\&H., R.A.M.C. Major R. D. GeORGe, M.B., B.S., R.A.M.C. CAPTAIN A. M. GRIEVE, M.B., ch.B., D.obst.R.C.o.G., D.C.H., R.A.M.C. CAPTAIN P. J. KAYE, M.R.C.S., L.R.C.P., D.obst. R.C.O.G., R.A.M.C.

M.R.C.Path. LIEUTENANT-Colonel J. R. Donaldson, M.B., Ch.B., D.R.C.Path., R.A.M.C. MajoR G. HUMPHRIES, M.A., B.M., B.Ch., D.R.C.Path., D.T.M.\&H., R.A.M.C.

D.Obst.R.C.O.G. MAJOR J. A. R. LONGWIIL, M.B., C.H.B., M.R.C.G.P., D.T.M.\&H., D.C.H., R.A.M.C. Captain D. A. D'Alton, M.B., B.ch., R.A.m.C. Captain G. D. MCEWan, M.B., Ch.B., R.A.M.C.

D.P.M. Lieutenant-Colonel K. N. Murray, m.B., ch.B., D.t.M. \&H., R.A.m.c. Captain D. A. CURSON, M.B., B.S., M.R.C.S., L.R.C.P., R.A.M.C.

P.Phys.Med. MAIOR G. O. HOPKINS, M.B., B.S., M.R.C.S., L.R.C.P., R.A.M.C.

\section{R.A.M.C. COURSE PRIZES}

\section{5 and 136 Postgraduate Medical Officers Course}

Sidney Herbert-Captain R. J. O'Sullivan

De Chaumont-Captain C. C. Spanswick

$J$. R. Rees-Captain R. J. O'Sullivan

Montefiore-Captain C. W. Borland
Parkes-Captain C. W. Borland

Ranald Martin-Captain R. J. O'Sullivan

Tulloch Memorial-Captain S. T. Inglis 